\title{
INFORMACION GENERAL
}

La Revista Mexicana de Astronomia y Astrofisica publica trabajos originales de investigación, $y$ ocasionalmente artículos de reseña, en todas las ramas de la astronomía, astrofísica y campos íntimamente vinculados a éstas. Normalmente aparecen dos números por año. Su distribución a las instituciones activas en los campos cubiertos por la Rev. Mex. Astron. Astrof. será gratuita. Se aceptarán gustosamente en canje revistas científicas.

Se reciben con placer trabajos para su posible publicación en la Rev. Mex. Astron. Astrof. Se recomienda a los autores consultar números recientes de la Revista para que usen su estilo en la preparación de los manuscritos, los cuales deberán ser sometidos por duplicado en español o en inglés, con resúmenes en ambos idiomas.

Se concede permiso a los autores de artículos y libros científicos de citar trabajos publicados en la Rev. Mex. Astron. Astrof. siempre y cuando se dé una referencia completa. La reproducción de figuras y tablas también se permite, bajo las mismas condiciones.

Los trabajos astronómicos editados en México antes de 1973, se encuentran en el Boletín de los Observatorios de Tonantzintla y Tacubaya. Números atrasados del Bol. Obs. Tonantzintla y Tacubaya, pueden obtenerse en la misma dirección de la Revista Mexicana de Astronomía y Astrofísica.
The Revista Mexicana de Astronomia y Astrofísica publishes original research papers and occasional review articles in all branches of Astronomy, Astrophysics and closely related fields. Two numben per year are issued normally. Distribution is free of charge to institutions engaged in the fields covered by the Rev. Mex. Astron. Astrof. Publications in exchange will be appreciated.

The submission of papers for publication in the Rev. Mex. Astron. Astrof. is welcome. Authors are advised to take recent issues of the Revista as sample of style for the preparation of the manuscript to be submited in duplicate in Spanish or English with an abstract in both languages.

Authors of scientific articles and books may quote from the Rev. Mex. Astron. Astrof. provided that reference to the source is given. Reproduction of figures and tables is permitted on the same basis.

Astronomical literature published in Mexico prior to 1973 is to be found in the Boletin de los Observatorios de Tonantzintla y Tacubaya. Back issues of the Bol. Obs. Tonantzintla y Tacubaya may be obtained at the address of the Revista Mexicana de Astronomía y Astrofísica. 


\section{REVISTA MEXICANA \\ DE \\ ASTRONOMIA Y ASTROFISICA \\ Mayo 1977}

OBSERVATIONAL PARAMETERS AND DYNAMICAL

EVOLUTION OF MULTIPLE STARS

Colloquium No. 33

International Astronomical Union

Oaxtepec, México

October 13-16, 1975

Dedicated to Dr. W. S. Finsen

Edited by Otto G. Franz and Paris Pismis, 